\title{
Analysis Of Virtual Product Marketing Strategies To Increase Customer Satisfaction (Case Study On Bukalapak Partners)
}

\author{
Jessica Artanti ${ }^{1}$, Prima M. Agustini ${ }^{2}$, Arief Saptono ${ }^{3}$, Gilang Kartika Hanum ${ }^{4}$, Regina \\ D..$^{5}$
}

Faculty of Economics and Business ${ }^{1}$, Faculty of Communication Science ${ }^{2}$, Faculty Information System ${ }^{3,4}$, Faculty of Science and technology 5 Bakrie University ${ }^{1,2}$, University of Raharja ${ }^{3,4,5}$

Kawasan Rasuna Epicentrum, JI. H. R. Rasuna Said No.2, RT.2/RW.5, Karet, Kecamatan Setiabudi, Kuningan, Daerah Khusus Ibukota Jakarta $12940^{1,2}$

Jl. Jenderal Sudirman No.40, RT.002/RW.006, Cikokol, Kec. Tangerang, Kota Tangerang, Banten $15117^{3,4,5}$ Indonesia

E-mail: admisi@bakrie.ac.id¹ ${ }^{1}$, prima.agustini@bakrie.ac.id², arief.saptono@raharia.info ${ }^{3}$, gilanghanum@raharja.info4 ${ }^{4}$, regina.dinda@raharja.info ${ }^{5}$

To cite this document:

Artanti, J. ., Agustini, P. M. ., Saptono, A. ., Kartika Hanum, G. ., \& Octavyra, R. D. . (2022). Analysis Of Virtual Product Marketing Strategies To Increase Customer Satisfaction (Case Study On Bukalapak Partners). IAIC Transactions on Sustainable Digital Innovation (ITSDI), 3(2), 86-109.

Retrieved from https://aptikom-journal.id/index.php/itsdi/article/view/516 DOI: https://doi.org/10.34306/itsdi.v3i2.516

\begin{abstract}
This study aims to analyze the marketing strategy of Mitra Bukalapak in increasing customer satisfaction. In this study, the researcher uses a qualitative approach, which aims to find out what strategies are used by Bukalapak's internal partners to increase Customer Satisfaction. The data used for this research are primary data and secondary data. The results of the research analysis using in-depth interviews with the internal parties of Bukalapak Partners and Bukalapak Partners as triangulators where they transact using the Bukalapak Partner application as a place to transact. The segment of Mitra Bukalapak is for all levels, where the initial target is the klontong shop and the product positioning offered is virtual and wholesale products. From the 7P marketing mix implemented by Bukalapak Partners internally, there are several strategies that still need to be addressed, one of which is the price strategy because the price is still a sensitive issue, especially for buyers who are pricesensitive. However, there are also strategies that have been created and implemented that can accepted by Bukalapak Partners.

Keywords: Marketing Strategy, Customer Satisfaction, 7P, E-Commerce, Mix Marketing.
\end{abstract}

\section{Introduction}

All companies, whether in the field of products or services, aim to survive and thrive. Progress in a highly competitive business world requires companies to be more innovative in providing attractive products to their customers [1],[2]. Without innovation, the company's products will be abandoned by customers, competing with other products that are increasingly filling the market [3]. On the other hand, customers are increasingly critical of what they get and expect from a product [4]. Failure to meet customer expectations will cause the company to lose the trust of customers as well as potential customers [5]. For a company to be 
successful, the selection and development of a marketing strategy are very important to meet the needs of its customers [6].

When developing a marketing strategy, managers must consider not only the needs of their customers but also the company's position in relation to its competitors. As a result, marketers must develop competitive marketing strategies to position themselves and constantly adapt their strategies to meet ever-changing competitors [4]. Customer satisfaction is the main key to a company's competitive advantage [7]. The reason is, customer satisfaction can have a positive impact on the company's performance and support its survival. This is the main reason every business acquires and retains customers [8].

The success of the company's product promotion is highly dependent on the implementation of marketing advice and strategies [9]. Because with the right marketing strategy, companies can create, maintain and develop consumer demand in a persuasive and sustainable manner [10]. If your turnover is growing slowly, you should consider whether this is due to an ineffective marketing strategy or changes in customer tastes and behavior. Marketing strategy is the starting point for successful large-scale production and communication with customers. Companies need to be precise when defining their STP marketing strategy that puts customer satisfaction first, and when marketing their products, they need to be aware of the marketing mix, which includes the seven marketing pillars [11].

Although many strategies and tactics are used, of the various e-commerce sites that sell virtual products, only Bukalapak and Tokopedia currently have a marketing strategy through partner programs. Bukalapak partners and Tokopedia partners seem to be trying hard to win the hearts of their customers. A very important difference between the Bukalapak Partner and the Tokopedia Partner itself is the guaranteed SLA and price, as well as the programs offered. Bukalapak has advantages and program features that can really satisfy its partners in the service sector, namely the SERU SERU, GEBRAKAN program. Comparison of the Bukalapak Partner application and the Tokopedia Partner.
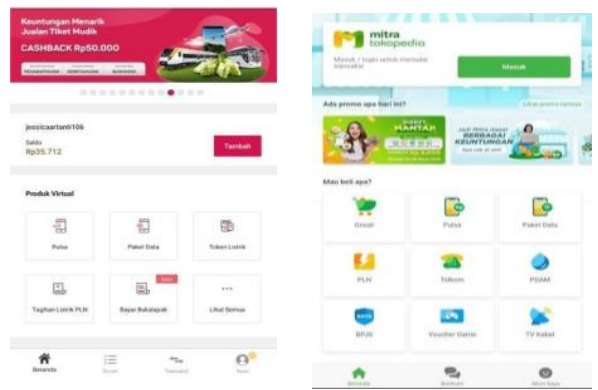

Figure 1. Bukalapak Partner Application and Tokopedia Partner

In the Mitra Bukalapak and Mitra Tokopedia applications on the home page, it can be seen that both have similarities, namely the interface for the virtual products sold along with the promotions provided by each market. Examples of user responses for Mitra Bukalapak and Mitra Tokopedia applications.
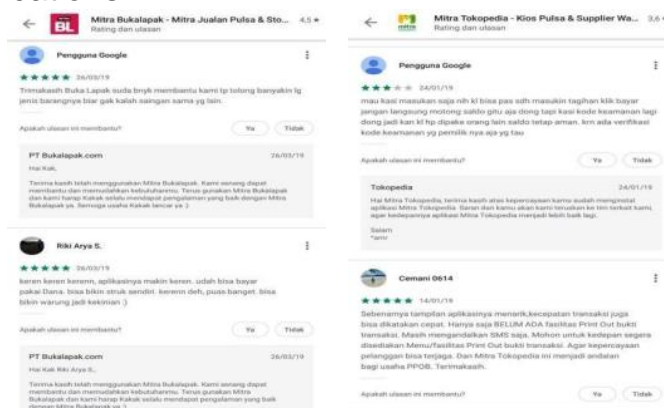

Figure 2. Customer Responses of Bukalapak Partners and Tokopedia Partners on the App Store 
In the App Store, you can see comments from each application and service user on Bukalapak and Tokopedia Partners. Through this marketing strategy, Bukalapak hopes to increase sales through Bukalapak Partners and understand the needs of each customer. Bukalapak can also find out customer needs based on existing segments. A good image and trust in the company will make customers make repeat purchases [12], and customers will not switch to other companies that offer similar products [4].

\section{Research Method}

The approach used in this study is a qualitative approach, namely a research approach without using statistical figures but with descriptive exposure, namely trying to describe a symptom, event, event that is happening at the present time, where the researcher tries to photograph events and events that occur to be the focus of his attention for later described as is [13],[14].

A case study is used as a comprehensive explanation relating to various aspects of a person, group, organization, program, or social situation that is being researched, pursued, and studied as deeply as possible [15]. Case studies also have a meaning related to detailed research about a person or a social unit over a certain period of time.

The empirical inquiry that investigates phenomena in real-life contexts, when; the boundaries between phenomena and contexts are not clearly defined and where: multiple sources of evidence are used [16]. As an inquiry, a case study does not have to be carried out in a long time, nor does it have to depend on ethnographic data or participant observation. A researcher can conduct valid and high-quality case studies without leaving the literature, depending on the topic to be investigated [17].

\subsection{Place and time of research}

Research on the Marketing Strategy of Virtual Products and Its Implications for Customer Satisfaction Case Study of Mitra Bukalapak, located installs or users of the Bukalapak Mitra Application who sell using a Bukalapak Partner account in the South Jakarta area. This research was conducted in November 2019.

\subsection{Data Collection Technique}

Data collection for case studies is in the form of documents, archive records, interviews, observations, and physical devices. For this reason, the data collection procedures used in this study were interviews, observations, and documentation [15].

a. In-depth interview (Interview).

The interview is a data collection technique to obtain in-depth information extracted from direct data sources or informants through conversation or question and answer [18]. An interview is a meeting of two people to exchange information and ideas through question and answer, so that meaning can be constructed in a particular topic [19]. Interviews in qualitative research are in-depth because they want to explore information holistically (original or pure) and clearly from informants [20].

Interviews or interviews are conducted with the principle of dialogue, discussion to build understanding and meaning in solving problems [21]. It can be done simultaneously with the observation of involvement (participants), document analysis, or other techniques [15]. In participant research, the researcher usually knows the subject first, so that the interview takes place like a friend's conversation [22]. Here interviews are difficult to separate from other research activities; even interviews are conducted without a formal introduction. However, towards the end of the study, when there is information that needs to be checked, the researcher can arrange a special time with the informant to conduct a more formal interview [15]. The main informant in this research is from Bukalapak, who is dedicated to Bukalapak Partners. 


\section{b. Observation}

The term observation is derived from Latin, which means "to see" and "to pay attention." The term observation is directed at the activity of paying attention to accurately, noting phenomena that arise, and considering the relationship between aspects of the phenomenon. This technique requires observations from researchers either directly or indirectly on the object of research. Instruments that can be used are observation sheets, observation guides [23]. Some information obtained from observations includes space (place), actors, activities, objects, actions, events or events, time, and feelings. The reason for the researchers to make observations is to present a realistic picture of behavior or events, answer questions, help understand human behavior, and evaluate, which is to measure certain aspects and provide feedback on these measurements [15].

\subsection{Data Analysis Techniques}

The data analysis technique in this research is the qualitative analysis technique. Qualitative research methods are research methods based on the philosophy of postpositivism, used to examine the condition of natural objects (as opposed to experiments) where the researcher is the key instrument, sampling data sources is carried out purposively, and snowball, data collection techniques with triangulation (combined), data analysis is inductive/qualitative, and qualitative research results emphasize meaning rather than generalization [13]. This definition provides an overview of how important the position of data analysis is in terms of research objectives. The main principle of qualitative research is to find theory from data.

Data analysis in qualitative research is carried out at the time of data collection and after completion of data collection within a certain period. At the time of the interview, the researcher had analyzed the answers of the interviewees. If the interviewee's answer after being analyzed feels unsatisfactory, the researcher will continue the question again.

\subsection{Data Validation}

To obtain the validity of the data, an examination technique based on several criteria is needed. Data validation in this qualitative research was carried out through extension of participation, triangulation. Extension of observation means research back into the field, making observations, interviewing again with data sources that have been encountered and new ones. Through the extension of this observation, it means that the relationship between the researcher and the resource person will be increasingly formed of mutual trust so that no information will be hidden.

After conducting interviews with the research subjects, the validity of the collected data was tested using the membercheck technique, namely the process of checking the data obtained by the researcher to the data provider. The purpose of member check is to find out how far the data obtained is in accordance with what is provided by the data provider. Checking is done by re-checking the information or opinion of the informant whether he stays with the information given, or will change or even deny it altogether.

Meanwhile, the triangulation of data in this study was carried out on informants who knew the research problem but were outside the research subject community. Researchers used triangulation on Mitra Bukalapak, namely those who have a shop called Toko Asep with Mr. Asep as the shop owner, Warung X with Mr. Wawan as the shop owner.

\section{Research Results And Discussion}

Mitra Bukalapak is an idea concept owned by Bukalapak. Bukalapak believes that by presenting a new innovation, namely Mitra Bukalapak, it can provide benefits for grocery stalls in Indonesia. Bukalapak itself is a provider of online buying and selling facilities from consumer to consumer, for individual and wholesale transactions, through mobile applications and websites. As the largest online market in Indonesia, Bukalapak plays an active role in the growth of national e-commerce by empowering Small and Medium Enterprises. $\mathrm{O} 2 \mathrm{O}$ is an ecommerce concept that connects online and offline channels. $\mathrm{O} 2 \mathrm{O}$ attracts users or customers 
through online media such as email, internet advertisements, and social media, then invites these customers to make purchases offline. This $\mathrm{O} 2 \mathrm{O}$ service allows customers to buy and pay online. Then pick up and return products offline at certain retail stores. Mitra Bukalapak is a program that allows individuals and shop owners to become partners. These partners can sell various products available at Bukalapak, ranging from daily necessities, telephone credit, to plane tickets. According to Bukalapak's Chief Strategy Officer, Teddy Oetomo, the plan to create this program has actually been around since 2016. The idea came from the Founder of Bukalapak, Achmad Zaky.

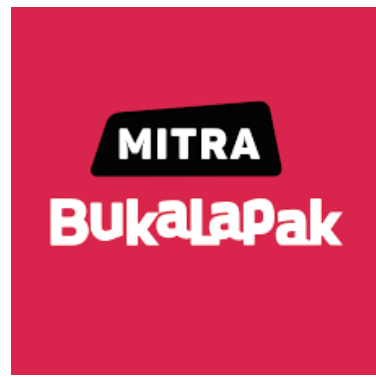

Figure 3. Bukalapak Partner Logo

(source: https://images.app.goo.gl/bReHzx7quMmGCuAb6)

The development of the e-commerce business world makes companies have to think creatively about the products that will be offered to customers. One product that is considered capable of increasing sales is a virtual product.

Virtual products or digital goods represent intangible goods such as memberships, services, guarantees, or subscriptions and digital downloads of books, music, videos, or other products (tolls, data packages, electricity tokens, postpaid products and game vouchers and tickets).

Although virtual products are not physical, they do represent something that can be sold and can be used as a business field such as selling pulses, electricity tokens as well as data packages. The following are the various virtual products that are sold at Mitra Bukalapak:

$$
\leftarrow \text { Produk Virtual }
$$

Figure 4. Virtual Products on Bukalapak Partners (Source: Bukalapak Partner Application)

\subsection{Research Result}

In the results section of this study, the results of the interviews will be presented which will be combined with the data findings and the findings will be linked to the theory used as the basis for this research.

As described in the framework, the author will focus on what the Bukalapak Partner team does on the elements that constitute the content of the marketing strategy. The results of 
this study will determine which elements are carried out by the Bukalapak Partner team as a marketing strategy and what the Bukalapak Partner team does on each of these elements to increase customer satisfaction.

\subsubsection{Marketing Strategy Findings at Bukalapak Partners}

In accordance with what has been discussed in the literature review, this research uses qualitative data collection by interview, the purpose of which is to see the implementation of marketing strategy and marketing mix which includes the 7P, namely the placement of Product, Price, Promotion, Place, People, Process and Physical Evidence on Partners. Bukalapak. The marketing strategy here is expected to provide an overview of whether it is appropriate so that it can increase customer satisfaction.

- Bukalapak Partner Segmentation

Market segmentation there are several variables that must be considered. The goal is that the segmentation carried out can be right on target. The segmentation of Bukalapak Partners was conveyed by the research subjects as follows:

"For Partners, the segment for the initial location in Jakarta, only in the end we will expand it, all ages, all occupations, anyone can become a Bukalapak Partner, because the product we want to introduce, all layers also need it. It's like credit, right, tokens, who doesn't need it, so anyone who wants to be a partner can do it, sell with us, give low prices, and the best service. So yes, the segment is anyone who wants to earn extra".

- Targeting Bukalapak Partners

Mentioned about the targeting strategy, the following is the explanation:

"The initial target was for grocery stalls, then it continued to reach students, so before that, anyone who wants to earn extra, who is linear in buying virtual products or if it's a shop, he can take wholesale. If it's a klontong shop, we'll acquire it. Because we also give our prices as low as possible, the target is people who need extra, and we will rebrand the stalls that we finally acquire according to our motto, namely the upscale stalls".

\section{- Bukalapak Partner Positioning}

If the target market (target program) is clear, positioning is how we explain the position of the product to consumers. What is the difference between our products and competitors and what are the advantages.

The following is an opinion regarding the positioning of Bukalapak Partners:

"First we are in virtual products, right after that we are wholesalers".

"So, let's sell the VP first, the VP goes, continues to deploy wholesalers, and thank God we go too".

\subsubsection{Bukalapak Partner Marketing Mix Findings}

After deciding all the segmentation, targeting and positioning of Bukalapak Partners, then plan or formulate a marketing mix or marketing mix which has 7 variables as follows:

- Findings of the Marketing Mix of Bukalapak Partners Product Strategy

In theory, products are all forms that are offered to the market for use or consumption so that they can meet market needs and wants. The product or service produced must have quality and uniqueness that is able to increase the competitiveness of the product or service in the market.

Based on the results of the interview, a number of information was obtained which revealed that the Bukalapak Partner team had products that were offered to Bukalapak partners. The following is the narrative of the research subject: "Ohh, so if 
there is a physical product or not, it's just that it covers all parts, meaning that it can be individual too, yes, the products we sell Chik, Virtual, have credit, data packages and tokens are top sellers" (Interview 26 November 2019).

Regarding top-selling products, the research subject stated the following: "Hmm, it's more about credit, because there are many providers and denominations, there may be people who buy high-denom or low-denom credits of five thousand or 100 thousand, and in Indonesia too. There are providers such as Telkomsel, Indosat, Smartfren, Tri, Axis, XL, where all people are different, so they use their cards and the needs of the pulses that occupy the standings are Telkomsel." (Interview 26 November 2019).

The same thing was also stated by the triangulator chosen by the author, who is a loyal Bukalapak Partner and has been a Bukalapak Partner for more than 1 year, Mr. W.

"Products, hm, pulses, Mba, many are looking for it, that's why I also often complain about pulses, which are the majority hahaha" (Interview 29 November 2019).

The statement from Mr. W was also strengthened by another triangulator, namely Mr. A.

"Hoo, yes, pulses are selling, yes, the same tokens are selling well, Mba, are bought by buyers." (Interview December 4, 2019).

When asked why the pulse product was selling well, the research subject stated:

"Because we give a guarantee too Chik"

"So if you buy credit from us, 15 minutes of credit hasn't arrived, we give you a refund guarantee, that's what I think, and our price for credit is also pretty good, moreover, of course, everyone needs credit, to make calls, to extend the active period. , to buy a data package, that's how it is." (Interview 26 November 2019).

Mr. W as a triangulator also stated the same thing with the research subject:

"I think it's just because of need, who doesn't need credit, right, even though it looks like Mba like WhatsApp, you can make calls, but sometimes it's intermittent, so it's better Just use a regular telephone and there are lots of products, and for the pulse, there are lots of choices." (Interview 29 November 2019).

And $\mathrm{Mr} \mathrm{W}$ added as well,

"So actually in terms of price it's quite okay" (Interview 29 November 2019).

Mr. A's statement regarding why the product is selling well in his shop is,

"What is it, maybe if you have credit you can make calls to family in the village, you can also make SMS, village people rarely have WhatsApp like that, Mba. So you still need credit, that's what I think, Mba." (Interview December 4, 2019).

Information from Mr. A when asked about the products offered by Bukalapak's internal partners, the following is his statement:

"Ho, yes, Ma'am, it varies, because there are out of a thousand, yes, and the good thing is that small credits rarely close, haha, sometimes they are closed, but at Mitra Bukalapak, they are open." (Interview December 4, 2019).

\section{- Findings of Bukalapak Partner's Price Strategy}

The price in question is the amount of money that must be paid by the user or partner to get the product offered. In other words, Partners will buy goods if the sacrifices incurred (i.e., money and time) are in accordance with the benefits that Partners want to get from the production of goods or services offered by the 
Bukalapak Partner team. So the focus on this point is how to make customers or potential buyers feel that their spending is in accordance with what they get, or in English terms commonly used "worth it".

The research subject provides answers regarding the strategy in determining the price given to Bukalapak Partners. Based on the results of interviews, obtained a number of information that reveals the strategy of the research subjects to determine the price for Mitra Bukalapak. The following is the statement of the research subject: "Just try and Error guys, what's certain is that you have to look at the competitors' prices, right? Stay aware of the budget hahaha. And of course we also have to look at the cost, we can't just give a cheap price right away" (Interview 26 November 2019).

The prices made by research subjects for each product vary, there are products that are sold far below competitors' prices. The following is the statement of the research subject:

"Hoo, there must be some, you can compare it, maybe not all of them, but there are. And that's because a lot of people buy it, it's a bestseller, apart from that, there's only a small amount of product" (Interview 26 November 2019).

Asked about whether the right price was given to Partners, the research subject stated that the prices given to Bukalapak Partners were quite competitive compared to other competitors. The following is the statement of the research subject:

"In my opinion, some are yes and some are not, as I said earlier, yes, so if there is a product that is indeed cheaper, and I can't lie, if there is one that is not cheaper. Moreover, the behavior of Partners is definitely looking for the really cheapest price that can turn out to be not from the competitors that we are highlighting. What's more, there are things that we really can't do anything about Chik, partner limitations because partners also give high prices, so it's also worth looking for other partners whose prices and quality are more competitive." (Interview 26 November 2019).

This was confirmed by Triangulator, Mr. W:

"Hahaha, yes, so actually in terms of the price it's pretty good, it's just that there are other sources, Mba, which are cheaper." "With quality, yes compared to yes, competing, Mba." (Interview 29 November 2019).

Mr. A as the second triangulator also stated the same thing:

"Okay Ma'am, it's okay. It's just that you go down again if you can, hahaha I'll take it thin because."

"If the price is okay, it's cheap, it's just that, haha, if I could reduce it again, I'd make more profit." (Interview December 4, 2019).

Mentioned about the prices given by the Bukalapak Partner team for Bukalapak partners, whether there were any differences, and this was conveyed by the research subject as follows:

"Why is there, a partner that we really give a special price, and yes, you are right, if that partner can contribute to a transaction, yes, I will give another price that is different" (Interview 26 November 2019).

\section{- The Findings of Bukalapak Partner Place Strategy}

The right distribution channel also determines the success or failure of the marketing strategy. Therefore, distribution channels occupy a crucial position in the marketing mix. The definition of the distribution channel itself is a variety of activities or any efforts made by the company to make its products or services easily obtained 
or available in the hands of consumers and customers. Because the purpose of distribution is to provide goods and services that consumers need and want at the right time and place, the ease of access and availability of products at the right outlets must also be considered by every company.

The following is the narrative of the research subject and the Triangulator regarding the Place Strategy regarding whether there are difficulties for Partners in conducting transactions, following W's statement:

"Difficult? If you ask me from my side, it's not difficult, because I also know how to join, even if someone doesn't know, I think it's easy because there is a guide, and every Experience Partner team goes to the shop, they will also explain how to become a Bukalapak Partner." (Interview 26 November 2019).

This is supported by the statement of Mr. W as a triangulator, when asked about the ease of transacting with the appearance of the Bukalapak Partner application.

"I'm still safe, okay, I understand Mba." (Interview 29 November 2019).

Given the same question, the following is the narrative of the second triangulator, namely Mr. A.

"I do understand, Mba, what's going on?

"Yes, so it's good, just click the menu and then that's it." (Interview December 4, 2019).

The research subject explained that before becoming a Partner, prospective Partners were given step-by-step education to understand starting from how to become a Partner and how to transact.

"That's right, step by step. Because we really want them to feel clear, right?" (Interview 26 November 2019).

However, triangulator Mr. W explained that sometimes he found it difficult to open applications because there was an issue that caused old applications to open

"Oh yes, I have, I reloaded again, then I can again"

"Sometimes it hangs, I can't make transactions, but after that I poked Mba Chika and usually I get info from Mba Chika when Bukalapak is down. Outside of that, it's fine, it's fine." (Interview 29 November 2019).

Mr. A's statement:

"Yes, I did, if I'm not mistaken it was when the lights went out at the same time, Mba. or when Bukalapak can't be accessed, or sometimes it doesn't come out like that Mba denom what I want to buy, doesn't come out like that, any products" (Interview December 4, 2019).

The following is a statement from the research subject regarding the issue of the process of opening the Bukalapak Partner application:

"We continue to do research, collect research, make improvements, so far, many partners have said it's okay, it's easy, it's just that sometimes there are issues, like it's hard to open, can't buy and get notifications, for example. But I do hope so, an update from us, which is also an idea from partners, can make the appearance of the Bukalapak Partner Application better in the future, don't worry, because Partners are also the container for this application, and we need it like that. Give and give each other." (Interview 26 November 2019).

\section{- Bukalapak Partner Promotion Strategy Findings}

The Promotion in question is an effort of persuasion (induction or 
encouragement) to invite consumers and potential consumers to buy (or use) products or services produced by a company. On the promotion strategy for Mitra Bukalapak, I interviewed the research subject. The first thing I asked was about the timing of the promo.

"If you look at how often, it really depends, if it's postpaid every month, but if it's prepaid because I think our credit prices are already cheap, we don't give promos every month, if it's tokens again, so yes, how often are postpaid promos? monthly routine, prepaid promos depend, not only once a month" (Interview 27 November 2019).

The Promotion given by the research subject was of interest to Mr. W as a Partner. Here's his narrative:

"Wow, I really like it, Mba. Because you can get more profit hahaha"

"If you're paying attention, actually, because sometimes I don't like it anymore, so when I see it, the period is over." (Interview 29 November 2019).

$\mathrm{Mr} \mathrm{A}$ also said something similar to $\mathrm{Mr} \mathrm{W}$

"Yes, I like it, only if the promo is more frequent with tokens, yes, it's the same as paying for electricity, as far as I know."

"Oh, if you pay often, often every month, the problem is, I also happen to be there for electricity, so just pay with a partner, you can make it yourself, right, Ma'am, yes, it's good to get extra money, what's that name, Ms. forgot hahaha" (Interview December 4, 2019).

Furthermore, the research subject explained the promotion strategy, from timing to how to inform the promo.

"If it's postpaid, we will increase the cashback, if it's prepaid, sometimes it's a direct discount, sometimes it's a voucher."

"Usually? If postpaid is usually 10 days before the due date of payment, the electricity bill and PDAM are paid every 15 to 20 and BPJS is from the 1st to the 11th, every month, so that's where we act. If you look at prepaid from internal needs, or you can also look at sales, the point is the promo is to attract sympathy, that's how it is, yes, yes, yes, if you ask the underlying factor, hmm, what is it, hahaha, I'm confused, the answer is, so yes, the factor is because there is an internal need. , to attract the sympathy of my beloved partners hahaha"

"What is certain is that we have woro-woro, whether it's a banner, push notification, keep looking at the need, that's what I said earlier, if postpaid is definitely approaching the due date, and thank God the goals continue." (Interview 27 November 2019).

Regarding promo strategies that are usually made by research subjects, and what types of promos are attracted by Bukalapak Partners, the research subjects explain that:

"If it's postpaid, we will increase the cashback, if it's prepaid, sometimes it's a direct discount, sometimes it's a voucher."

"Ho, it's definitely a direct discount because if it's a voucher, it's more effort for them, they don't really like many steps and things like that." (Interview 27 November 2019).

Regarding the promotion strategy that partners are interested in conveyed by the research subject, Mr. W as the triangulator justifies:

"That's a discount, Ma'am, if you can get a big discount, you don't need vouchers, because sometimes vouchers can't be used like that, right. If the price is discounted, it can definitely be used."

"Yes Ma'am, I'll pay right away hahaha (no need to use a voucher)" 
(Interview 29 November 2019).

Mr. A's statement regarding the promotion strategy:

"I don't like anything, right, but do you want cashback, Ma'am, the price goes down directly, Mba."

"Sometimes the voucher runs out, even though l've only used it once, sometimes it's 9 in the morning when it's gone." (Interview December 4, 2019).

\section{- The Findings of Bukalapak Partners People Strategy}

The human resource factor determines the progress of a company or not. This is why various companies are competing to find the best job candidates; they are even willing to pay more to hire independent job seekers who are experts in finding job candidates for companies.

An attractive and relaxed work culture is usually used as an added value that is proud of by a company to make its employees loyal and maximal at work. The following is the narrative of the research subject and the Triangulator regarding the People Strategy, mentioned about the internal treatment of the Bukalapak Partner for the Bukalapak Partner, the following is the narrative from the source of the research subject:

"If we are based on the principle of Bukalapak, one value is Customer Obsessed, so if you are asked how we treat it, we try our best, try to understand and be there when they need it, of course we try to give certainty to each of their complaints, so Don't hang it for long." (Interview 26 November 2019).

The research subjects also stated that not all Partners could understand the shortcomings of transacting at Mitra Bukalapak, but the research subjects had ways to make Partners comfortable in submitting complaints:

"Hmm, not anymore, being said, sworn in, ever hahaha, that's all I consider a risk from that kind of work and maybe they don't mean it like that either because maybe they are pressured by the customer too, because it's different, right? -each partner, some are patient and their grammar is good to hear, some are just like that hahaha."

"What is certain is that we have to be calm, keep trying to listen to whatever Partners need, in as much detail as possible, please make sure when it will be solved." (Interview 26 November 2019).

Mentioned about the top complaint, the following is the narrative of the research subject:

"Many complaints, yes, credit, credit has not arrived but money has been withdrawn, because sales of credit are also high, so many are related to credit, there are also those who complain even though they have not entered the SLA." (Interview 26 November 2019).

The research subject emphasized his remarks regarding the guarantees given regarding solved problems, namely regarding ETA so that complaints can be immediately updated and guarantees can be given to Partners:

"1x24 hours, that's the maximum, we are trying to push the related team so that before that $1 \times 24$ hours we can update regarding the complaint. But for tokens for 10 minutes, autorefund, and pulses for 15 minutes, yes, if you have already made a complaint."

"We really try not to do more, if it's more, yes, a refund guarantee."

(Interview 26 November 2019).

This was confirmed by the triangulator, namely Mr. A, when asked about the 
complaint process, Mr. A gave the following statement:

"That's Mba, who I said at the beginning, yes, it's easy to inform if there is an issue, and often it's over quickly, if it's in other places but it's not like the Bukalapak model, it takes a while to finish it." (Interview December 4, 2019)..

Mr. W as another Triangulator also emphasized the complaint process:

"It's easy, Ma'am, it's easy, it's not difficult, I think it's quite responsive." (Interview 29 November 2019).

Mr. A added about the hope for handling complaints related:

"Wow, I'm confused, okay Ma'am, maybe in the future, hmm, what do you want, Mba, okay, Ma'am, let's just make it faster. Because sometimes I'm stuck like that, haa, what's that, hm, yes, the buyer. It's also awkward haha" (Interview December 4, 2019).

\section{- Bukalapak Partner Process Strategy Findings}

The process in question is a sequence of interrelated executions or events which then together convert inputs into outputs (inputs). The following is an explanation from research subjects and triangulators regarding the transaction process by becoming a Bukalapak Partner.

The research subject gave a statement when mentioned about the security provided by the Bukalapak Partner team to the Bukalapak Partner:

"We have an anti-fraud team where the team is dedicated to guarding that, so that we don't get caught. If a fraudster starts to smuggle in, or there is an account that is indeed an indication of fraud, we will immediately cut it out." (Interview 26 November 2019).

Regarding the guarantee of losses suffered by Partners due to Fraudster, the research subjects gave the following statements:

"It depends, if it's the negligence of the Partner, we can't give a guarantee, for example the user/partner clicks the link that the fraudster gives to the user, gives the OTP to the fraudster with the lure of getting a gift from Bukalapak, because we were always informed from the start education if this cannot be done. So what can be guaranteed is that the condition is not the fault of the account owner. For example, those who run on Partners have their accounts hacked by the Sales Army because when they register they know the MBL password." "(guarantee) 100\% money back." (Interview 26 November 2019).

Mr. W as a triangulator told his experience of being hit by a hack and treat given by the Bukalapak Partner team:

"It's safe, it's safe Ms. Because I was hacked once, Mba hahaha, the money immediately ran out of 10 million, thank God Ms, because of the fast response from CS friends and the policy from Bukalapak, finally my money came back, helped to lock the account to make it more secure." (Interview 29 November 2019).

Regarding the convenience of transacting, the research subjects gave a description of how to make Bukalapak Partners feel comfortable in transacting:

"What is certain is that we do a review related to the User Interface, as much as possible to minimize all kinds of bugs or hangs that make Partners take a long time to click, just don't make it difficult for Partners to make transactions, moreover, Partners definitely want to hurry up and finish it quickly. That's how it is because the consumers are waiting for them, yes, it's the same, and yes, we'll try to give you a look where the 
meaning of the writing isn't complicated, and the language is easy to understand so there's no misunderstanding."

"We are well aware that maybe we have not fully understood the layers of each Partner, and we continue to research, visit, so that in the future what Partners hold, see and use for transactions, as if it were the Partner hm the Partner make the language like that." (Interview 26 November 2019).

Mentioned about the difficulties in the application that hangs, the following is the narrative of the research subject:

"Ho, in this case, it usually hangs, it takes a long time to say, but actually it can be because of the network, yes, but hahaha, we also try to look at the log from the transaction process, and we review it, or maybe suddenly we can't choose nominal, can't proceed to payment." (Interview 26 November 2019).

Mr. W as a triangulator conveyed about the comfort in transacting as a Bukalapak Partner:

"It's convenient, isn't it because of that, I feel that everything can be finished quickly if there are problems, so it's comfortable." (Interview 29 November 2019).

The research subject also added about the actions taken:

"Usually we know there is a problem if there is a complaint, yes, of course I will immediately raise it to the engineer so I will try to investigate so that in the future it doesn't happen again." (Interview 26 November 2019).

When asked about the appropriate value given to all Bukalapak Partners, the following is the statement of Mr. W and Mr. A as Triangulators:

Mr W's words:

"Me, hm how much is it haha 5 Mba l'll give you"

"Because I also took it from other e-commerce, only at Bukalapak, where the price, speed and service made me feel at home, Mba." (Interview 29 November 2019).

Mr. A's words:

"I dare to give 5 Mba."

"Haha, yes, it's worth it, it's worth it, because of this, Ma'am, I took it from Partners, not only credit, there were also basic necessities, now the price given is okay, the service if you complain is also okay." (Interview December 4, 2019).

\section{- Physical Evidence Strategy Findings for Bukalapak Partners}

The last process of the marketing mix is Physical Evidence, which is how we as internal parties try to brand the products that we will offer to users and have unique values if they are seen.

The research subject as the branding team, gave a statement regarding the physical evidence from the Bukalapak Partner:

"Bakkael Partners, if the Partner owns a shop, what really makes the difference is our rebranding to Mitra Bukalapak, we give banners, we give flyers, we give barcode scans, everything is red, which red is the identity of Bukalapak, right? . Well, there is also something, we'll prepare it like hemm, what's the name, like a bill and there's an inscription Mitra Bukalapak, as proof of payment." (Interview 28 November 2019).

However, for partners who do not have a stall, the research subject states that there is no branding yet:

"There is no special branding yet for individuals, because usually individuals are rich enough to buy tickets or tokens for the office or even for personal consumption, so 
nothing reaches consumers like that."

"Because we are rebranding the shop." (Interview 28 November 2019).

Mr. W's words as a Bukalapak Partner regarding the branding of his shop:

"Wow, you know, haha, there's a big banner in front of the counter, and there's Mba Siti Badriah's face. So once, Mba, my neighbors didn't know the name of my counter, finally they said, "That's a shop covered by a red banner, which is Mitra Bukalapak" hahaha." (Interview 29 November 2019).

Mr. W's words as a Bukalapak Partner regarding the branding of his shop:

"As for Partners, I think you know, there's a big red sign, it says MITRA BUKALAPAK hahaha." (Interview 29 November 2019).

\subsubsection{Customer Satisfaction according to Bukalapak's Internal Partners}

Making Partners satisfied is a point that is always expected by each service provider. Attached are the results of interviews with research subjects regarding customer satisfaction in the internal version of Mitra Bukalapak.

Research subjects convey the meaning of customer satisfaction as follows:

"Yes relative yes"

"Satisfaction must be measured by service that meets expectations." "Because it's fast, cheap, smooth, that's all, what I said earlier, is relative." "They may repeat orders, so by impact, we can help increase their business efficiency."

Mentioned about the importance or not of Customer Satisfaction on Bukalapak Partners, the following is the narrative of the research subject:

"Wow, yes, Chik, it's very important"

"Yes, if Partners are not satisfied, the business will not be sustainable. In accordance with our values, right, one of them is Customer Obsessed, so the focus is on the customer. Customercentric."

According to the research subject, the least amount of complaints does not mean Partners are satisfied with the internal marketing strategy of Bukalapak Partners. Here's the expression: "I can't, because who knows there is someone who is in a "lazy" position to complain, actually wants to but is lazy. Go Chik. We avoid buyers' hard complaints, yes. We make transactions not hanging, too yes."

The research subject also conveyed about the internal ways of Partners so that Bukalapak Partners were more satisfied to transact:

"This routine evaluation is for the strategy, creating a new routine program. And of course, we must have a threshold related to daily transaction users, our services must be improved continuously. Because it could be, the transaction partner is fast, but our service is bad, how about that. It's also tangled, later the customer will get angry, keep leaving. We try to minimize things like that."

Research subjects explained that all Partners should be treated fairly: "Supposedly, without being selective, everyone should be served. Remember the same value."

\section{- Supporting and Inhibiting Factors of Bukalapak Partner's Marketing Strategy}

1. Supporting Factors for Bukalapak Partner's Marketing Strategy

In the making until the formation of a marketing strategy, there will always be factors that support so that it can provide success and smoothness of the marketing strategy. The following describes the results of interviews regarding the factors supporting the 
marketing strategy

The research subject explains what factors are supporting factors for marketing strategy:

"We have a lot of products, hmm, the choices are virtual or wholesale, we can dare to guarantee transaction updates, then we also have a solid CS team, ready 7/24. Yes, I think it is a contributing factor, and yes, there are many more."

2. The Inhibiting Factors of Bukalapak Partner's Marketing Strategy

In addition to supporting factors, marketing strategies also have inhibiting factors, research subjects convey the inhibiting factors as follows:

"If it's a barrier from our side, hmm, the partners are not adequate, so if they give a low price, our budget is also limited, while we have to give a low price, we are demanding, then sometimes we make plans, for example, we want to promote the budget, Chik, or just right I had to deploy another team, rework it, yes and that's it, technical, yes, non-technical."

The research subject also conveyed additional information in dealing with the inhibiting factors, following the narrative of the research subject:

"For partners, look for more, so that we have more sources than now if for other internals, we will make plans $123 . "$

\subsection{Discussion}

Analyzing marketing strategies in increasing customer satisfaction, using a qualitative approach, and looking at internal and external factors, both of which are used as research subjects and triangulators. Triangulator is a Bukalapak Partner who actively transacts using the Bukalapak Partner application.

Mitra Bukalapak's internal team has several strategies in satisfying customers in transactions; this is supported by the two triangulators, who indeed also confirm a lot of what the internal team has stated in determining marketing strategies.

\subsubsection{Segmenting, Targeting, Positioning}

After conducting internal interviews, the implementation of the marketing strategy carried out by Mitra Bukalapak internally is by choosing to formulate the target market using the Segmenting, Targeting and Positioning methods. The segmentation of the Bukalapak Partner is for all levels of society who want to earn additional income; this segment applies because of the concept of Bukalapak itself which is a marketplace or place to sell which is not limited to anyone who will be a seller as well as a buyer. For internal positioning, Mitra Bukalapak provides a variety of products at competitive prices and non-stop services are available.

\subsubsection{Marketing Mix}

After deciding on all segmentation, targeting and positioning, Mitra Bukalapak internally plans or formulates a marketing mix that has 7 variables as follows:

- Product

Product is anything that is offered to the market to get the attention of buyers, users, or consumers. The product strategy carried out internally by Mitra Bukalapak is to sell Virtual Products, which products consist of credit, data packages, electricity tokens, bills, tickets. In addition, Mitra Bukalapak internally also provides non-virtual products, namely wholesale products that can be purchased by Mitra users who own stalls.

- Price

The price of an item or service is a determinant of market demand, the price can affect the company's competitive position and also affect its market share. Based on the results of pricing interviews with Bukalapak Partners through comparisons from other competitors, looking at the base price, and trial error when pricing in strategy 1 , and the results after that will be evaluated. Mitra Bukalapak internal party admits that for virtual products, there are indeed some prices that are not cheaper than competitors' prices. 
- Place

All Bukalapak Partners can transact through the Bukalapak Partner application, or the Marketplace application but must have an account registered as a Partner.

- Promotion

Promos are given by Bukalapak's internal partners for virtual products quite often, the term is monthly, but it's unfortunate that the products that are often given promos are postpaid products, where sales of prepaid products, especially credit, also have the opportunity to increase sales. Information about ongoing promos can be seen on the Bukalapak Partner application or Instagram from the Bukalapak Partner internally.

- People

Humans in this case are employees who are internal partners of Bukalapak, who are always in touch with all kinds of complaints from Bukalapak partners, namely the CS team. The Bukalapak Partner CS team has non-stop operating hours or 7/24. The CS team is also equipped with the ability to interact properly and appropriately with Bukalapak Partners so that Bukalapak Partners feel comfortable to convey all input.

- Process

The transaction process for Bukalapak Partners is very easy, besides that security and convenience in the transaction process are considered very necessary to be developed, because if the process is tough, it will make Partners dissatisfied. The internal partner of Bukalapak continues to strive to avoid fraudulent attempts or hackers who try to enter the Bukalapak Partner's account.

- Physical Evidence

The rebranding of the shop is one of the internal strategies of Bukalapak Partners to be able to make Bukalapak Partners unique and memorable for their buyers. Branding with red background paint, a red banner with the words Mitra Bukalapak written on it, is one of the strategies so that Bukalapak Partners looks different from other stalls that are not Bukalapak Partners.

There are also internal and external factors that are supporting and inhibiting which are also the basis for the satisfaction of Bukalapak Partners or not, the following SWOT analysis [24] table is attached.

Table 1. SWOT Analysis

\begin{tabular}{|l|l|}
\hline \multicolumn{1}{|c|}{ Strength } & \multicolumn{1}{c|}{ Weakness } \\
\hline $\begin{array}{l}\text { Money-back guarantee if the product is not } \\
\text { received. }\end{array}$ & Lack of Promotion on best-selling products. \\
\hline CS team with 7x24 operating hours. & Pricing policy. \\
\hline Update transactions no more than 1x24 hours. & Maintenance from time to time. \\
\hline Product diversity. & The occasional application. \\
\hline A number of various powders. & Demanding related to stock of goods and prices \\
\hline & \\
\hline $\begin{array}{l}\text { The product offered is a product that is needed } \\
\text { by everyone. }\end{array}$ & The emergence of new partners. \\
\hline $\begin{array}{l}\text { Bukalapak partners have more than 3 million } \\
\text { registered users, which for inactive users will } \\
\text { continue }\end{array}$ & Similar competition from other e-commerce. \\
\hline treated with retention. & $\begin{array}{l}\text { There are external issues that cannot be } \\
\text { handled by internals, such as issues at the } \\
\text { provider. }\end{array}$ \\
\hline
\end{tabular}


Table 2. IFAS and EFAS Analysis

\begin{tabular}{|c|c|c|}
\hline \multirow{5}{*}{ IFAS } & Strength (S) & Weakness (W) \\
\hline & $\begin{array}{l}\text { Money-back guarantee if } \\
\text { the product is not received. }\end{array}$ & $\begin{array}{l}\text { Lack of Promotion on best- } \\
\text { selling products. }\end{array}$ \\
\hline & $\begin{array}{l}\text { CS team with } 7 \times 24 \\
\text { operational hours. }\end{array}$ & Pricing policy. \\
\hline & $\begin{array}{l}\text { Update transactions no } \\
\text { more than } 1 \times 24 \text { hours. }\end{array}$ & $\begin{array}{l}\text { Maintenance from time to } \\
\text { time. }\end{array}$ \\
\hline & Product diversity. & The occasional application. \\
\hline \multirow[b]{2}{*}{ EFAS } & A large number of partners. & \multirow{2}{*}{$\begin{array}{l}\text { Demanding related to stock } \\
\text { of goods and prices. }\end{array}$} \\
\hline & $\begin{array}{l}\text { High level of security with } \\
\text { the OTP feature. }\end{array}$ & \\
\hline Opportunity (O) & Strategi SO & Strategi WO \\
\hline $\begin{array}{l}\text { Internet that reaches almost all } \\
\text { corners of Indonesia so that } \\
\text { Bukalapak can reach all of Indonesia. } \\
\text { In addition, with internet technology, } \\
\text { consumers from abroad can also } \\
\text { access Bukalapak so that Bukalapak's } \\
\text { market reach is wider. }\end{array}$ & $\begin{array}{l}\text { Hold an interesting } \\
\text { invitation to find new } \\
\text { Partners. }\end{array}$ & $\begin{array}{l}\text { Make promotions more } \\
\text { active and more attractive. }\end{array}$ \\
\hline $\begin{array}{l}\text { The government is committed to } \\
\text { encouraging the growth of the e- } \\
\text { commerce industry in Indonesia. }\end{array}$ & $\begin{array}{l}\text { Holding regular meetings } \\
\text { with Bukalapak Partners or } \\
\text { ex- Bukalapak Partners to } \\
\text { create and continue to } \\
\text { maintain good } \\
\text { relationships. }\end{array}$ & $\begin{array}{l}\text { Create special promos to } \\
\text { attract new partners or } \\
\text { partners who haven't } \\
\text { transacted for a long time. }\end{array}$ \\
\hline $\begin{array}{l}\text { The consumptive lifestyle of the } \\
\text { Indonesian people can be used to } \\
\text { bring benefits to Bukalapak and the } \\
\text { sellers on the Bukalapak site. }\end{array}$ & $\begin{array}{l}\text { Improve the capabilities of } \\
\text { the Partner's internal team, } \\
\text { especially communication } \\
\text { between (CS) and } \\
\text { Partners. }\end{array}$ & $\begin{array}{l}\text { Implement a more } \\
\text { competitive pricing strategy. }\end{array}$ \\
\hline \multirow[b]{2}{*}{$\begin{array}{l}\text { Mitra Bukalapak has more than } 3 \\
\text { million registered users, of which } \\
\text { inactive users will continue to be } \\
\text { treated with retention. }\end{array}$} & $\begin{array}{l}\text { Increase speed in the } \\
\text { transaction process. }\end{array}$ & \multirow[b]{2}{*}{$\begin{array}{l}\text { Setting a price strategy to } \\
\text { attract old Partners to trade } \\
\text { again. }\end{array}$} \\
\hline & $\begin{array}{l}\text { Providing Partner rewards } \\
\text { for Partners who are able } \\
\text { to sell virtual products at } \\
\text { Bukalapak Partners with a } \\
\text { minimum transaction } \\
\text { target. }\end{array}$ & \\
\hline Threats $(T)$ & Strategi ST & Strategi WT \\
\hline The emergence of new partners. & Improve product quality. & $\begin{array}{l}\text { Improve the system to avoid } \\
\text { bugs or hangs. }\end{array}$ \\
\hline
\end{tabular}




\begin{tabular}{|l|l|l|}
\hline \multirow{2}{*}{$\begin{array}{l}\text { Similar competition from other e- } \\
\text { commerce. }\end{array}$} & $\begin{array}{l}\text { Innovate and improve } \\
\text { product quality in order to } \\
\text { outperform the competition } \\
\text { between similar } \\
\text { companies. }\end{array}$ & $\begin{array}{l}\text { Price negotiation with } \\
\text { partners. }\end{array}$ \\
\cline { 2 - 3 } & Improved service quality. & $\begin{array}{l}\text { Make promotions of } \\
\text { attractive products to attract } \\
\text { new partners. }\end{array}$ \\
\hline \multirow{2}{*}{$\begin{array}{l}\text { There are external issues that cannot } \\
\text { be handled by internals, such as } \\
\text { issues at the provider. }\end{array}$} & $\begin{array}{l}\text { Improve good } \\
\text { communication from } \\
\text { internal to external } \\
\text { (Partners) }\end{array}$ & $\begin{array}{l}\text { Looking for new suppliers } \\
\text { who can provide stable } \\
\text { products and more } \\
\text { competitive prices }\end{array}$ \\
\cline { 2 - 3 } & Create unique programs. & \\
\hline
\end{tabular}

\subsubsection{Product Variation}

The virtual product provided by the Bukalapak Partner team has variations that other Partners don't have. So that Bukalapak Partners can choose which products are in accordance with consumer needs.

\subsubsection{Customer Obsessed}

In every transaction it doesn't always go well, sometimes things don't go smoothly. Instantly the customer felt that the transaction was unsatisfactory, in fact, there was a complaint that was submitted through the internal CS team. Mitra Bukalapak's internal CS has operating hours of 7/24 and always applies to be able to understand and provide comfort to customers, so that customers feel that they are embraced and accepted in submitting their complaints.

\subsubsection{Service Level Agreement}

The Service Level Agreement or commonly known as the guarantee or certainty of updates from Bukalapak's internal partners for Bukalapak's partners, which the Bukalapak Partner team feels the need to implement is because the certainty of transactions must have a bright spot, without lingering waiting for time. This transaction update guarantee is called $1 \times 24$ hours.

Table 3. Supporting Factors of Bukalapak Partner's Marketing Strategy

\begin{tabular}{|c|l|l|}
\hline No & \multicolumn{1}{|c|}{ Supporting Factors } & \multicolumn{1}{c|}{ Analysis } \\
\hline 1 & Various Product & $\begin{array}{l}\text { Bukalapak partners have products that vary from 1000 (pulse), } \\
\text { which of the many products, the product is expected to be } \\
\text { accessible to all levels of society. }\end{array}$ \\
\hline 2 & Customer Satisfaction & $\begin{array}{l}\text { Mitra Bukalapak has an internal CS team that is very fast in } \\
\text { serving customers, whose operating hours are full time 7 days 24 } \\
\text { hours. }\end{array}$ \\
\hline 3 & $\begin{array}{l}\text { Service Level } \\
\text { Agreement }\end{array}$ & $\begin{array}{l}\text { By becoming a Bukalapak Partner, you can be guaranteed a } \\
\text { transaction in which there is an SLA update limit for 1 } \times 24 \text { hours. }\end{array}$ \\
\hline
\end{tabular}

\subsubsection{Budget}

The budget or budget of the company that has been divided by proportion, sometimes this is one of the reasons for the inhibiting factor of Bukalapak's marketing strategy, because product prices from suppliers are high and one way to be able to sell products at competitive prices is to use the budget that has been given. , but it is undeniable that even though 
Bukalapak Partners have been scheming in the pricing strategy, there are still many other partners who can provide low prices. Because price is still a crucial thing that can make partners who are price sensitive choose other parties who provide low prices.

\subsubsection{Promotion}

Providing promos that are not well targeted also makes Bukalapak Partners feel less interested in participating in ongoing promos because promotions are given quite often for postpaid products where the majority of sales are prepaid products. Apart from that, the promotion method with vouchers is also considered more difficult than the promo method with direct discounts.

\subsubsection{Demand to Supplier}

Increased sales but not supported by a diversity of suppliers (partners) can hinder Bukalapak's marketing strategy. This is because if you have a dependence on suppliers, and the supplier cannot provide the best quantity and quality performance, the internal partner of Bukalapak also has no other choice and without having to follow the game from the supplier.

Table 4. Inhibiting Factors of Bukalapak Partner's Marketing Strategy

\begin{tabular}{|c|l|l|}
\hline No & \multicolumn{1}{|c|}{ Obstacle Factor } & \multicolumn{1}{c|}{ Analysis } \\
\hline 1 & Budget & $\begin{array}{l}\text { Budget or budget is one of the internal inhibiting factors for } \\
\text { Bukalapak Partners. This is because the price is the basis of the } \\
\text { Partner's main interest in increasing the transaction quantity (if } \\
\text { given a low price) }\end{array}$ \\
\hline 2 & Promotion & $\begin{array}{l}\text { The uneven Promotion of all virtual products and the lack of } \\
\text { precise targeting of the promos made the promotion strategy less } \\
\text { acceptable to all Bukalapak Partners. }\end{array}$ \\
\hline 3 & Demand to Supplier & $\begin{array}{l}\text { Having few partners (suppliers) makes Bukalapak Partners } \\
\text { internal too dependent, this is also an inhibiting factor, this is } \\
\text { because there are no other varied options to determine which } \\
\text { product from the supplier is selected based on the performance } \\
\text { and the basic price given. }\end{array}$ \\
\hline
\end{tabular}

3.2.9 The Most Major Marketing Strategies Appear

After being interviewed by Research Subjects and Triangulators (Mitra Bukalapak), the two Triangulators stated that the People Strategy implemented by the Bukalapak Partner team dominated in increasing customer satisfaction, followed by Product. This is evidenced by the second statement of the Triangulator during the interview process. Both agreed that Triangulator felt comfortable to raise complaints when transacting at Bukalapak Partners. In contrast to other e-commerce, at Bukalapak Partners are given certainty in transactions, coupled with a responsive Bukalapak Partner CS team in handling complaints from Bukalapak Partners. 
Table 5. The Most Important Bukalapak Partner Marketing Mix Strategies

\begin{tabular}{|c|c|l|l|}
\hline No & Informant & \multicolumn{1}{|c|}{ Marketing Strategy (Product) } & \multicolumn{1}{|c|}{ Analysis } \\
\hline 1 & Mr W & $\begin{array}{l}\text { "...In my opinion, it's just because of need, } \\
\text { right, who doesn't need credit, right, even } \\
\text { though it's like Mba, like WhatsApp, you can } \\
\text { make calls, but sometimes it's just } \\
\text { intermittent, so it's better to just use a } \\
\text { regular phone, yes, there's a lot of products, } \\
\text { right? Keep going } \\
\text { There are also many choices for pulses..." } \\
\text { (Results of the interview, November 29, } \\
\text { 2019) }\end{array}$ & $\begin{array}{l}\text { Mr. W considers that the virtual } \\
\text { products offered by Bukalapak's } \\
\text { internal partners have many } \\
\text { variations, and one of the best- } \\
\text { selling products in the market is } \\
\text { credit products. Mr. W is } \\
\text { satisfied because Bukalapak } \\
\text { internally provides lots of credit } \\
\text { options. }\end{array}$ \\
\hline \multirow{2}{*}{ Mr A } & $\begin{array}{l}\text { "...Ho, yes, Ma'am, it varies, because there } \\
\text { are out of a thousand, yes, and the good } \\
\text { thing is that the small credit rarely closes } \\
\text { haha sometimes it's closed here but at Mitra } \\
\text { Bukalapak it's open..." (Interview result } \\
\text { December 4, 2019) }\end{array}$ & $\begin{array}{l}\text { Mr. A stated the same thing as } \\
\text { Mr. W, and Mr. A added that } \\
\text { there are several pulse products } \\
\text { with low denom that are } \\
\text { currently not available on other } \\
\text { patforms, but these products } \\
\text { are still available at Mitra } \\
\text { Bukalapak. }\end{array}$ \\
\hline
\end{tabular}

\begin{tabular}{|c|c|l|l|}
\hline No & Informant & \multicolumn{1}{|c|}{ Marketing Strategy (People) } & \multicolumn{1}{c|}{ Analysis } \\
\hline 1 & Mr W & $\begin{array}{l}\text { "... Easy Mba, it's easy, it's not difficult, I think } \\
\text { it's quite responsive..." (Interview 29 } \\
\text { November 2019) }\end{array}$ & $\begin{array}{l}\text { Mr. W considers that when you } \\
\text { want to submit a transaction } \\
\text { complaint, the Bukalapak Partner } \\
\text { CS team is responsive and } \\
\text { no trouble. }\end{array}$ \\
\hline 2 & Mr A & $\begin{array}{l}\text { "... it's easy to inform if there is an issue, and } \\
\text { often it's done quickly, if it's in other places but } \\
\text { it's not like the Bukalapak model, it takes a } \\
\text { while to finish ..." (Interview result December } \\
4,2019)\end{array}$ & $\begin{array}{l}\text { Mr. A considers that if you } \\
\text { complain, quickly solve it if it has } \\
\text { been raised to the Bukalapak } \\
\text { Partner CS team. }\end{array}$ \\
\hline
\end{tabular}

When compared to Tokopedia Partners, the two have differences. Here's the comparison:

\section{- Display (User Interface)}

Mitra Bukalapak and Mitra Tokopedia carry almost the same theme in appearance. The difference is that the icon on Mitra Bukalapak is more minimalist with all the features hidden, while Mitra Tokopedia has a bigger icon and all the features are one on the front page. Here's how it looks: 


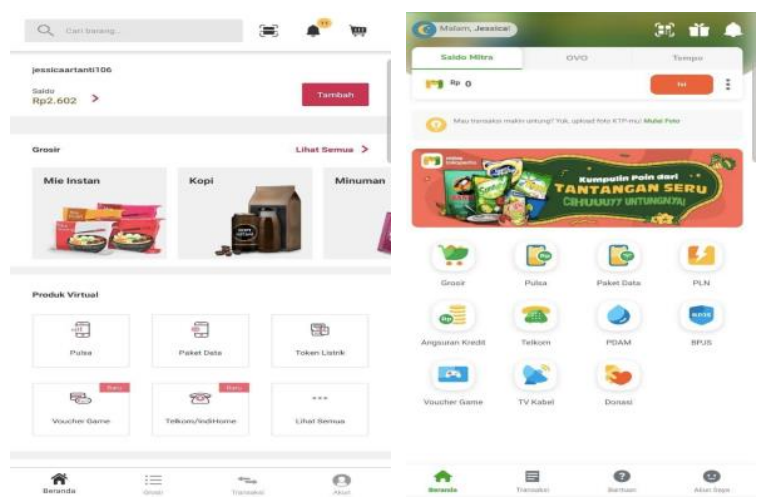

Figure 5. User Interface of Bukalapak Partner and Tokopedia Partner Feature

\section{- Feature}

Mitra Bukalapak has 11 features for virtual products and 17 SKUs for wholesale products. Meanwhile, Mitra Tokopedia has 11 features, of which 10 are virtual products.

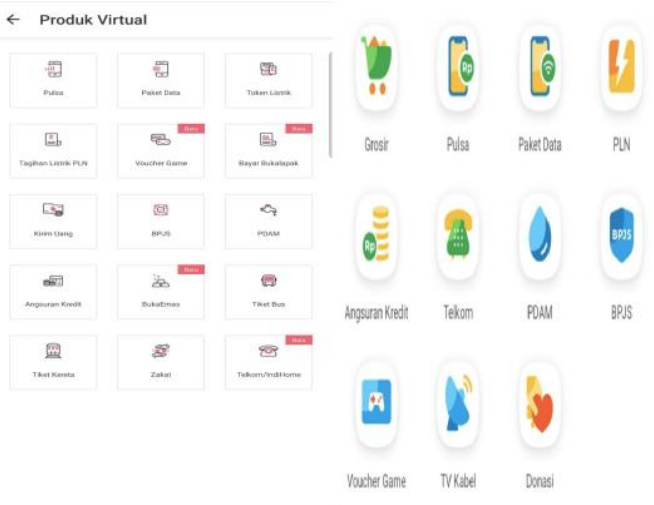

Figure 6. Virtual Products of Bukalapak Partners and Tokopedia Partners

\section{- Price Comparison}

The comparison of virtual product prices between Bukalapak Partners and Tokopedia Partners is difficult to compare. This is because each has a product price where some are cheaper and some are more expensive.
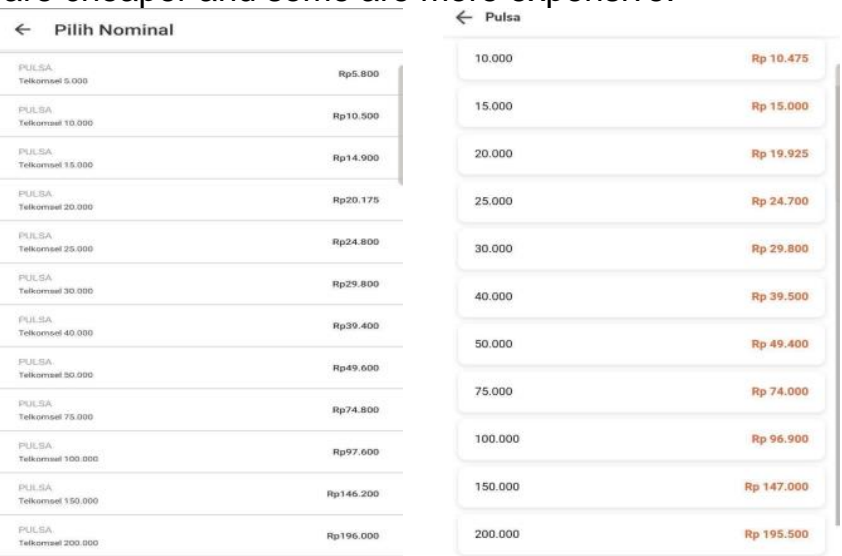

Figure 7. Telkomsel Credit Prices for Bukalapak Partners and Tokopedia Partners 


\section{- Top Up Balance}

At Mitra Bukalapak, the top up balance starts from 50,000 to 5 million rupiah, but you can choose another nominal which means it can be up to 5 million rupiah. Meanwhile, for Mitra Tokopedia, the top-up balance starts from a nominal 10,000 to 10 million rupiah.
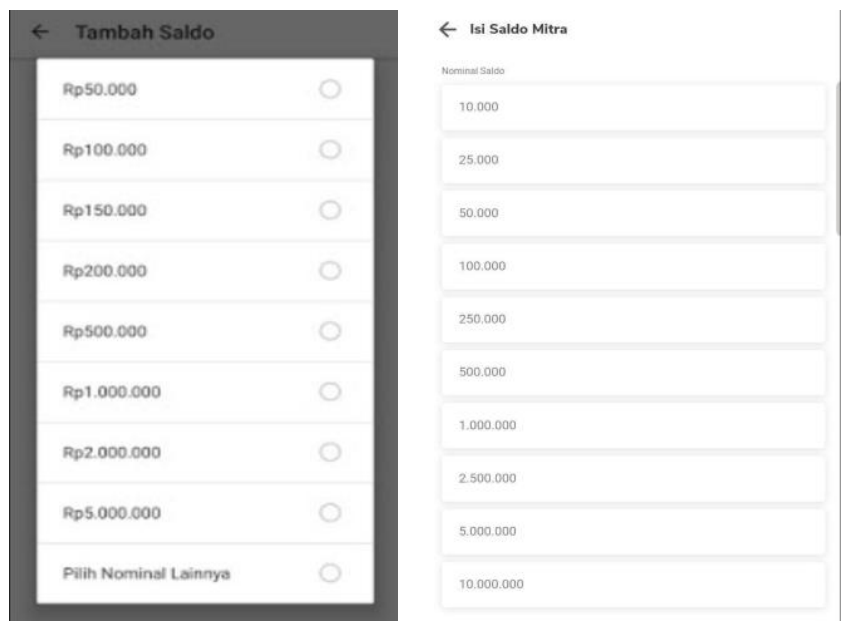

Figure 8. Top Up Balance of Bukalapak Partners and Tokopedia Partners

\section{Conclusion}

Based on the results of research that has been carried out on PT Bukalapak (Mitra Bukalapak), it can be concluded that the results of the Bukalapak Partner's internal interview, customer satisfaction is very important because this can make the business sustainable, and Bukalapak's internal partners will continue to evaluate sustainable marketing strategy in order to continue to create and increase the satisfaction of Bukalapak Partners. In carrying out a marketing strategy, Bukalapak Partners create segmentation for Bukalapak partners for all circles, the initial target is a grocery shop in the South Jakarta area and the product positioning is virtual products and wholesalers. the results of the internal and external interviews of Bukalapak Partners, which concluded that the marketing mix strategy implemented by Bukalapak's internal partners consisted of Product, Price, Place, Promo, People, Process, Physical Evidence. Of the seven components of the marketing strategy, People and Product are the main factors revealed by the two triangulators as the things that make them continue to transact with Bukalapak Partners. Mitra Bukalapak internal parties also continue to strive to always improve strategies if they are not appropriate with the aim of continuing to satisfy customers, because the internal value of Bukalapak itself is Customer Obsessed, where customer satisfaction is an important thing that must be continuously improved.

Regarding the Supporting Strategies and Barrier Strategies of the marketing mix strategy that has been implemented. The price strategy is still the main inhibiting factor that must be continuously evaluated in the marketing strategy, because there are still many partners who are price-sensitive and partners will continue to choose the cheapest prices, so if Bukalapak's internal partners cannot provide the cheapest prices due to budget constraints, partners will switch to competitors or other platforms. Budget also affects the promos given, confirmed by triangulators; they feel that promos for best-selling products are rarely given by Bukalapak partners. However, in addition, there are factors that support the strategy, namely various products as well as services from Bukalapak's internal partners who are non-stop and can receive all kinds of complaints from Partners as well as certainty regarding the transaction updates that are complained of. 


\section{References}

[1] E. Oztemel and S. Gursev, "Literature review of Industry 4.0 and related technologies," J. Intell. Manuf., vol. 31, no. 1, pp. 127-182, 2020.

[2] W. Liu and K. Atuahene-Gima, "Enhancing product innovation performance in a dysfunctional competitive environment: The roles of competitive strategies and marketbased assets," Ind. Mark. Manag., vol. 73, pp. 7-20, 2018.

[3] P. Edastama, N. Lutfiani, U. Rahardja, S. Avionita, and P. A. Sunarya, "Overview of Business Innovation and Research Probability on Blockchain and Introduction to its Exclusive Version," in 2021 3rd International Conference on Cybernetics and Intelligent System (ICORIS), 2021, pp. 1-7.

[4] P. Kotler, H. Kartajaya, and I. Setiawan, "Marketing 3.0: From products to customers to the human spirit," in Marketing wisdom, Springer, 2019, pp. 139-156.

[5] M. Adam, M. Wessel, and A. Benlian, "Al-based chatbots in customer service and their effects on user compliance," Electron. Mark., vol. 31, no. 2, pp. 427-445, 2021.

[6] S. Kingsnorth, Digital marketing strategy: an integrated approach to online marketing. Kogan Page Publishers, 2019.

[7] R. Ramlawati and A. H. P. Kusuma, "Total Quality Management as the Key of the Company to Gain the Competitiveness, Performance Achievement and Consumer Satisfaction," Int. Rev. Manag. Mark., vol. 8, no. 5, p. 60, 2018.

[8] R. East, J. Singh, M. Wright, and M. Vanhuele, Consumer behaviour: Applications in marketing. Sage, 2021.

[9] F. Schiavone and M. Simoni, "Strategic marketing approaches for the diffusion of innovation in highly regulated industrial markets: the value of market access," J. Bus. Ind. Mark., 2019.

[10] S. Nam and H. Hwang, "What makes consumers respond to creating shared value strategy? Considering consumers as stakeholders in sustainable development," Corp. Soc. Responsib. Environ. Manag., vol. 26, no. 2, pp. 388-395, 2019.

[11] R. W. Palmatier and S. Sridhar, Marketing strategy: Based on first principles and data analytics. Bloomsbury Publishing, 2020.

[12] R. B. Kim and Y. Chao, "Effects of brand experience, brand image and brand trust on brand building process: The case of Chinese millennial generation consumers," J. Int. Stud., vol. 12, no. 3, 2019.

[13] H. K. Mohajan, "Qualitative research methodology in social sciences and related subjects," J. Econ. Dev. Environ. People, vol. 7, no. 1, pp. 23-48, 2018.

[14] E. Dolan and A. S. Bein, "Implementation of Student Performance Management Guidance to Improve Quality Study at Colleges," IAIC Trans. Sustain. Digit. Innov., vol. 1, no. 2, pp. 160-171, 2020.

[15] D. R. Hancock, B. Algozzine, and J. H. Lim, "Doing case study research: A practical guide for beginning researchers," 2021.

[16] S. Ebneyamini and M. R. Sadeghi Moghadam, "Toward developing a framework for conducting case study research," Int. J. Qual. Methods, vol. 17, no. 1, p. $1609406918817954,2018$.

[17] K. Vasileiou, J. Barnett, S. Thorpe, and T. Young, "Characterising and justifying sample size sufficiency in interview-based studies: systematic analysis of qualitative health research over a 15-year period," BMC Med. Res. Methodol., vol. 18, no. 1, pp. 1-18, 2018.

[18] A. M. Solarino and H. Aguinis, "Challenges and best-practice recommendations for designing and conducting interviews with elite informants," J. Manag. Stud., vol. 58, no. 3, pp. 649-672, 2021.

[19] K. Roulston and M. Choi, "Qualitative interviews," SAGE Handb. Qual. data Collect., pp. 233-249, 2018.

[20] N. Jentoft and T. S. Olsen, "Against the flow in data collection: How data triangulation combined with a 'slow'interview technique enriches data," Qual. Soc. Work, vol. 18, no. 2, pp. 179-193, 2019.

[21] D. E. Gray, Doing research in the real world. Sage, 2021.

[22] B. L. Read, "Serial interviews: When and why to talk to someone more than once," Int. 
J. Qual. Methods, vol. 17, no. 1, p. $1609406918783452,2018$.

[23] A. Hinsley, A. Keane, F. A. V St. John, H. Ibbett, and A. Nuno, "Asking sensitive questions using the unmatched count technique: Applications and guidelines for conservation," Methods Ecol. Evol., vol. 10, no. 3, pp. 308-319, 2019.

[24] M. Rakhmansyah, U. Rahardja, N. P. L. Santoso, A. Khoirunisa, and A. Faturahman, "Smart Digital Signature berbasis Blockchain pada Pendidikan Tinggi menggunakan Metode SWOT," ADI Bisnis Digit. Interdisiplin J., vol. 2, no. 1, pp. 39-47, 2021.

[25] Jayabuana, N. (2018). Mitra Tokopedia Meluncur, Persaingan O2O Kian Keras. Bisnis Indonesia November, $\quad 15, \quad 2018, \quad$ from https://teknologi.bisnis.com/read/20181115/84/860337/mitra-tokopedia-beroperasi-dibekasi-persaingan-o2o-kian-keras.

[26] https://id.wikipedia.org/wiki/Bukalapak. Diakses pada tanggal 27 Maret 2019.

[27] https://www.bukalapak.com/bantuan/mitra-o2o/tentang-mitra/tentang-mitra- bukalapak . Diakses pada tanggal 29 Maret 2019.

[28] https://en.wikipedia.org/wiki/Tokopedia . Diakses pada tanggal 29 Maret 2019.

[29] https://www.tokopedia.com/blog/press-release-mitra-tokopedia/ . Diakses pada tanggal 29 Maret 2019.

[30] https://www.dewaweb.com/blog/marketing-mix/. Diakses pada tanggal 28 Desember 2019. 